\title{
KORUPSI LEGISLASI DALAM PEMBENTUKAN PERATURAN PERUNDANG-UNDANGAN
}

(Legislative Corruption in Law Making Process)

\author{
Akhmad Adi Purawan \\ Kementerian Sekretariat Negara R.I. \\ JI. Veteran No. 17 Jakarta \\ Email:akhmad_adi@setneg.go.id
}

Naskah diterima: 15 Oktober 2014; revisi: 24 Nopember 2014; disetujui: 28 Nopember 2014

\begin{abstract}
Abstrak
Meskipun Indonesia telah memiliki Undang-Undang Nomor 10 Tahun 2004 tentang Pembentukan Peraturan Perundangundangan yang selanjutnya disempurnakan dengan Undang-Undang Nomor 12 Tahun 2011, tetapi kerawanan dalam proses pembentukan peraturan peraturan perundang-undangan yang mengarah pada bentuk perilaku koruptif masih terjadi. Dengan menggunakan metode yuridis normatif, studi ini mencari jawaban atas pertanyaan apakah pengaturan dalam Undang-Undang Nomor 12 Tahun 2011 telah mengantisipasi terjadinya korupsi legislasi dalam pembentukan peraturan perundang-undangan. Studi ini menyimpulkan bahwa secara normatif Undang-Undang Nomor 12 Tahun 2011 sudah cukup antisipatif dalam menciptakan mekanisme pembentukan peraturan perundang-undangan yang mengarah pada bentuk pencegahan terhadap praktik korupsi legislasi. Namun, perwujudan pembentukan peraturan perundangundangan yang baik dan bersih sangat tergantung pada kualitas pelaksanaannya. Dari lima tahapan pembentukan peraturan perundang-undangan, studi ini menemukan tahap perencanaan dan pembahasan mengandung kerawanan yang cukup tinggi, sedangkan pada tahap penyusunan, penetapan/pengesahan, dan pengundangan kecil kemungkinan terjadi. Untuk meminimalisasi peluang terjadinya korupsi legislasi, studi ini mengusulkan empat prinsip yang dapat diterapkan, meliputi ketatalaksanaan, profesionalitas, justifikasi, dan partisipasi publik.
\end{abstract}

Kata Kunci: legislasi, kerawanan, korupsi

\section{Abstract}

Indonesia has Law Number 10 year 2004 on drafting of the laws then its superseded by Law Number 12 year 2011 but the vulnerability in the law making process that lead to corruptive behaviour remain happens. By using juridical normative methods, this study seeks answers whether the regulation in the Law Number 12 year 2011 have been anticipating for the vulnerability of legislative corruption in law making process. This study conclude that normatively Law Number 12 year 2011 has been quite anticipative in forming mechanism of law making process which is lead to prevent legislative corruption practices. However, the embodiment of clean and good establishment of legislation is depend on the quality of its implementation. Among the stages of law making process, this study found that planning and discussion stages are quite vulnerable to legislative corruption, while preparation, enactment, and promulgation less likely occured. In order to minimize possibility of legislative corruption, this study proposes four principles can be applied icluded the management, professionalism, justification, and public participation.

Keywords: legislative, vulnerability, corruption 


\section{A. Pendahuluan}

Undang-Undang Dasar Negara Republik Indonesia Tahun 1945 menyatakan bahwa Negara Indonesia adalah negara hukum. Prinsip tersebut mengandaikan kepada setiap elemen negara baik penyelenggara kekuasaan pemerintahan negara, penyelenggara kekuasaan lain dalam negara, maupun rakyat wajib mendasarkan setiap perilakunya berdasarkan hukum. Sebagai negara hukum, segala aspek kehidupan dalam bidang kemasyarakatan, kebangsaan, dan kenegaraan termasuk pemerintahan harus berdasarkan atas hukum.

Dalam arti sempit, hukum sering dimaknai sebagai peraturan perundang-undangan. Peraturan perundang-undangan adalah peraturan tertulis yang memuat norma hukum yang mengikat secara umum yang dibentuk atau ditetapkan oleh lembaga negara atau pejabat yang berwenang melalui prosedur yang ditetapkan. Ada dua sifat yang terkandung dari pengertian tersebut, formal dan material. Sifat formal menentukan bahwa peraturan perundang-undangan dibentuk atau ditetapkan oleh lembaga negara atau pejabat yang berwenang melalui prosedur yang ditetapkan. Sifat material menentukan bahwa peraturan perundang-undangan memuat norma hukum yang mengikat secara umum.

Dalam rangka mewujudkan Indonesia sebagai negara hukum dan memenuhi kebutuhan masyarakat atas peraturan perundang-undangan yang baik, Presiden dan DPR telah menetapkan Undang-Undang Nomor 10 Tahun 2004 tentang Pembentukan Peraturan Perundang-undangan yang mengatur prinsip, prosedur, dan teknik pembentukan peraturan perundang-undangan yang mengikat semua lembaga yang berwenang membentuk peraturan perundang-undangan. UndangUndang Nomor 10 Tahun 2004 pada dasarnya dibentuk untuk memenuhi perintah Pasal 22A Undang-Undang Dasar Negara Republik Indonesia Tahun 1945 dan Pasal 6 Tap MPR No. III/MPR/RI Tahun 2000 tentang Sumber Hukum dan Tata Urutan Peraturan Perundangundangan. Jauh sebelum Undang-Undang Nomor 10 Tahun 2004 dibentuk, Indonesia memiliki regulasi pembuatan peraturan perundang-undangan dalam bentuk UndangUndang dan Keppres ${ }^{1}$, namun karena adanya 
perubahan Undang-Undang Dasar Negara Republik Indonesia Tahun 1945, khususnya Pasal 20 ayat (1) yang menentukan bahwa DPR memegang kekuasaan membentuk UndangUndang, maka berbagai peraturan perundangundangan tersebut sudah tidak sesuai lagi. Pada tahun 2011, dalam rangka penyempurnaan dan menampung perkembangan kebutuhan masyarakat mengenai pembentukan peraturan perundang-undangan yang baik, UndangUndang Nomor 10 Tahun 2004 diganti dengan Undang-Undang Nomor 12 Tahun 2011.

Prinsip negara hukum sendiri sebenarnya bukanlah hal baru dalam kehidupan bernegara Indonesia. Prinsip negara hukum bahkan dinyatakan secara tegas sebagai salah satu bagian dari sistem pemerintahan negara². Dalam penjelasan UUD 1945 original dinyatakan bahwa Negara Indonesia berdasar atas hukum (rechtsstaat), tidak berdasarkan atas kekuasaan belaka (machtsstaat). Dalam perubahan UUD 1945, prinsip tersebut selanjutnya "diangkat" ke dalam batang tubuh. Selain dimaksudkan untuk menormakan hal-hal pokok yang dimuat dalam penjelasan UUD 1945 original dalam batang tubuh UUD 1945 hasil perubahan ${ }^{3}$, penormaan prinsip negara hukum tersebut dilatarbelakangi oleh praktik pemerintahan orde baru yang ditunjukkan dengan lemahnya supremasi hukum terhadap kekuasaan ${ }^{4}$.

Sayangnya, sejalan dengan bergesernya kekuasaan membentuk undang-undang dari Presiden ke DPR, penyimpangan kewenangan dalam pembentukan peraturan perundangundangan nampaknya juga ikut bergeser dari eksekutif ke legislatif. Komisi Pemberantasan Korupsi (KPK) misalnya dalam suatu studi mengenai korupsi di DPR menengarai bahwa korupsi di DPR tidak hanya terjadi pada fungsi anggaran dan pengawasan, namun terjadi pula dalam fungsi legislasi ${ }^{5}$. Kenyataan tersebut mengejutkan banyak orang karena selama ini locus korupsi lebih sering terjadi pada fungsi anggaran.

Dalam kajian mengenai korupsi di negaranegara ex-komunis di Eropa Timur dan Asia Tengah, World Bank membagi tipe korupsi menjadi dua: administrative corruption dan state capture $^{6}$. Administrative corruption meliputi tindakan kesengajaan untuk menghambat pelaksanaan kebijakan, keputusan, atau ketentuan peraturan perundangundangan yang berlaku untuk memperoleh keuntungan pribadi, sedangkan state capture

2 Lihat Berita Republik Indonesia Tahun II No. 7 tanggal 15 Februari 1946 dalam Saafroedin Bahar, et al., Risalah Sidang Badan Penyelidik Usaha-Usaha Persiapan Kemerdekaan Indonesia (BPUPKI)-Pantia Persiapan Kemerdekaan Indonesia (PPKI) 28 Mei 1945-22 Agustus 1945 (Jakarta: Sekretariat Negara RI, 1995)..

3 Penormaan hal-hal normatif Penjelasan UUD 1945 dalam batang tubuh merupakan salah satu dari 5 kesepakatan dasar pembahasan perubahan UUD 1945. Lihat Majelis Permusyawaratan Rakyat Republik Indonesia, "Hasil Perubahan dan Naskah Asli UUD 1945", dalam Panduan Pemasyarakatan Undang-Undang Dasar Negara Republik Indonesia Tahun 1945 (Jakarta: Sekretariat Jenderal MPR RI, tahun 2005), hlm. 14-15..

4 Tim Penyusun Revisi Naskah Komprehensif Perubahan Undang-Undang Dasar Negara Republik Indonesia Tahun 1945, Latar Belakang, Proses, dan Hasil Pembahasan 1999-2002, Buku II Sendi-Sendi/Fundamental Negara (Jakarta: Sekretariat Jenderal dan Kepaniteraan Mahkamah Konstitusi: 2010), hlm 390.

Komisi Pemberantasan Korupsi, "DPR Masih Rawan Korupsi", Komisi Pemberantasan Korupsi, http://kpk.go.id/ id/berita/berita-sub/1358-dpr-masih-rawan-korupsi (Diakses 1 Oktober 2014).

6 World Bank, Anticorruption in Transition: A Contribution to the Policy Debate, (Washington D.C.: World Bank, 2000), hlm. xv-xvii. 
mengacu pada tindakan individu, kelompok, atau korporasi baik di sektor publik dan swasta untuk mempengaruhi pembentukan perundang-undangan, keputusan, atau kebijakan pemerintah untuk keuntungan individu, kelompok, atau korporasi tersebut. Administrative corruption terjadi dalam konteks implementasi kebijakan, keputusan, atau ketentuan peraturan perundangundangan sedangkan state capture terjadi dalam perumusan kebijakan, keputusan, atau ketentuan peraturan perundang-undangan.

Korupsi yang terjadi dalam pembentukan peraturan perundang-undangan dapat dimasukkan dalam pengertian state capture. Dalam state capture, terdapat dua aktor yang bermain: kelompok kepentingan dan pembentuk undang-undang. Kelompok kepentingan memiliki misi mendorong peraturan perundang-undangan yang disusun agar mengarah pada bentuk-bentuk perilaku monopolistik sehingga dapat menghasilkan keuntungan sebanyak-banyaknya (supernormal profit) dan mempertahankan market powernya. Disisi lain, pembentuk undang-undang mengharapkan uang atau prospek keuntungan pribadi lainnya dari kelompok kepentingan tersebut sebagai imbalan atas "jasa" yang telah dilakukan. Dibandingkan dengan administrative corruption, korupsi legislasi memiliki efek merusak yang lebih besar karena dapat berdampak pada distorsi pengaturan yang menyebabkan eksternalitas negatif bagi masyarakat secara keseluruhan.
Berkaca pada uraian diatas, persoalan yang penting untuk dikaji adalah apakah pengaturan dalam Undang-Undang Nomor 12 Tahun 2011 telah mengantisipasi terjadinya korupsi legislasi dalam pembentukan peraturan perundangundangan? Untuk dapat mengetahui hal ini maka tulisan ini akan menjelaskan terlebih dahulu terlebih dulu bagaimana konfigurasi pembentukan peraturan perundang-undangan saat ini.

\section{B. Metode Penelitian}

Studi ini mengambil obyek Undang-Undang Nomor 12 Tahun 2011 tentang Pembentukan Peraturan Perundang-undangan dan produk hukum terkait yang berkaitan dengan pembentukan peraturan perundang-undangan. Metode yang digunakan adalah yuridis normatif dengan fokus kajian pada celah korupsi legislasi dalam pembentukan peraturan perundangundangan sebagaimana diatur dalam UndangUndang Nomor 12 Tahun 2011 berdasarkan kajian literatur dan studi pustaka yang dianalisis secara kualitatif dan menguraikannya secara preskriptif, serta apa yang menjadi penyebab korupsi legislasi.

\section{Pembahasan}

\section{Konfigurasi Politik Pembentukan Peraturan Perundang-undangan}

Peraturan perundang-undangan mengandung dua makna: produk dan proses ${ }^{7}$. Sebagai suatu produk, peraturan perundang-undangan bukanlah merupakan suatu konsep tunggal. 
Sebagaimana ditunjukkan pada namanya, ia merupakan pengertian kumpulan (verzameld begrip) yang didalamnya tercakup berbagai jenis peraturan perundang-undangan, mulai dari tingkat yang paling tinggi sampai yang paling rendah. Begitu pula sebagai proses, pembentukan berbagai jenis peraturan perundang-undangan tersebut memiliki proses tersendiri yang dalam beberapa hal berbeda, disamping mengandung pula persamaan, antara jenis peraturan yang satu dengan lainnya.

Proses lahirnya suatu produk peraturan perundang-undangan setidaknya melewati 3 (tiga) koridor yang saling terkait; koridor administrasi, koridor akademik, dan koridor politik ${ }^{8}$. Koridor administrasi mensyaratkan dipatuhinya segala ketentuan yang mengatur mengenai proses pembentukan peraturan perundang-undangan; koridor akademik menghendaki suatu rancangan peraturan harus dapat dipertanggungjawabkan secara akademik; koridor politik tidak saja menyangkut kelembagaan politik tetapi secara substansi rancangan peraturan tersebut harus mampu menyerap dan sejalan dengan aspirasi publik. Oleh karena itu, lahirnya suatu peraturan perundang-undang merupakan hasil dari suatu proses yang tidak sederhana, bahkan dapat dikatakan kompleks karena banyak faktor dan aktor terkait yang harus mendapat perhatian dalam proses tersebut.

Otto, Stoter, dan Arnscheidt setidaknya telah meringkas lima teori yang menggambarkan konfigurasi faktor dan aktor dalam pembentukan peraturan perundang-undangan, yaitu synoptic policy-phases theory, the agenda-building theory, the elite ideology theory, the bureaupolitics theory or organizational politics theory, dan the four rationalities theory ${ }^{9}$.

Dalam synoptic policy-phases theory, proses pembentukan undang-undang diandaikan sebagai suatu proses yang terorganisasi dengan baik dan terarah dari bentuk pengambilan keputusan yang mengikat yang bertujuan untuk memberikan arah bagi masyarakat secara keseluruhan. Berdasarkan teori ini, kebijakan dikembangkan di bawah naungan lembaga-lembaga yang akuntabel secara politik, yang masing-masing memiliki peran sendiri dimana aktor politik adalah orang-orang yang bertanggung jawab dalam menentukan isi dari hukum yang hendak dibentuk. Sebaliknya dalam the agenda-building theory, proses pembentukan undang-undang diandaikan sebagai suatu proses yang tidak terorganisasi dengan baik dan terarah yang dihasilkan dari proses sosial di mana ide-ide dan kepentingan yang berbeda berbenturan. Dalam situasi yang demikian, kelompok-kelompok yang berkepentingan berupaya mendapatkan akses pada agenda politik untuk dapat menawarkan konsep pengaturan peraturan perundangundangan.

Dalam the elite ideology theory, proses pembentukan peraturan perundang-undangan dilatarbelakangi oleh ambisi dari elit politik yang terinspirasi oleh jargon, nilai, ideologi, atau prinsip baru (informing principle) yang

8 Yusril Ihza Mehendra, "Bahan Penjelasan Mensesneg pada Rapat Kerja dengan Komisi II DPR RI tanggal 25 Januari 2006" (Disampaikan pada Rapat Kerja Menteri Sekretaris Negara - Komisi II DPR RI, Jakarta, 25 Januari 2006)..

9 J.M. Otto, W.S.R. Stoter, J. Arnscheidt, J., Using legislative Theory to Improve Law and Development Projects", RegelMaat afl. 2004/4: 121-135. 
berasal dari negara/kelompok masyarakat lain yang dianggap lebih maju dan modern untuk kemudian diterapkan dalam masyarakatnya yang penyusunannya sendiri tidak melibatkan masyarakat. Persoalannya, jargon, nilai, ideologi, atau prinsip baru (informing principle) tersebut pada umumnya tidak sesuai dengan realitas sosial masyarakat sehingga pada akhirnya hanya menciptakan resistensi dan bahkan stagnasi.

Dalam the bureau-politics theory or organizational politics theory, proses pembentukan peraturan perundang-undangan bukanlah dibentuk atas dasar formasi yang rasional atau proses yang didorong oleh masyarakat melainkan hanya perebutan wewenang antar lembaga negara. Bervariasinya bidang tugas dan rentang kendali masingmasing lembaga negara menyebabkan setiap pembahasan rancangan peraturan perundangundangan baru memunculkan ego sektoral diantara lembaga-lembaga tersebut dimana setiap lembaga berusaha untuk membawa substansi yang dibahas dalam rentang kewenangannya.

Dalam the four rationalities theory, peraturan perundang-undangan memiliki empat dimensi yang setiap dimensinya memiliki rasionalitasnya masing-masing. Keempat dimensi tersebut meliputi: dimensi politik, hukum, ekonomi dan ilmu pengetahuan. Keempat dimensi tersebut terkadang berjalan beriringan, terkadang berjalan sendiri-sendiri atau bahkan saling mereduksi satu dengan lainnya. Di negara berkembang, dimensi politik biasanya lebih mendominasi dibandingkan dengan dimensi hukum, ekonomi, dan ilmu pengetahuan karena di negara berkembang pada umumnya tatanan poilitik yang ditetapkan sangat berdampak pada kehidupan masyarakat. Sebaliknya, di negara maju dimensi politik pada umumnya tidak lebih mendominasi dibandingkan dengan dimensi hukum, ekonomi, dan ilmu pengetahuan.

\section{Penyebab Korupsi Legislasi}

Di Indonesia, korupsi legislasi belum banyak diulas dalam kajian hukum dan sosial. Selama ini kajian mengenai korupsi lebih banyak fokus pada tindakan kejahatan seperti penyuapan, penggelapan atau penyalahgunaan wewenang yang dilakukan dalam konteks implementasi peraturan perundang-undangan yang disebut oleh World Bank sebagai administrative corruption. Sedangkan bentuk-bentuk korupsi politik yang disebut oleh World Bank sebagai state capture masih terbilang jarang dibahas oleh ahli Indonesia.

Konsep World Bank mengenai state capture sendiri sebetulnya dibangun dari konsep regulatory capture yang dicetuskan pertama kali oleh Stigler $(1971)^{10}$. Munculnya teori regulatory capture dilatarbelakangi oleh pertanyaan filosofis mengenai apa yang sebetulnya memotivasi pembentuk undang-undang anggota parlemen, pemerintah, atau badan regulasi membuat suatu undang-undang yang 
mengikat publik? Apakah untuk menyuguhkan kebijakan yang terbaik bagi masyarakat, ataukah termotivasi dengan prospek keuntungan pribadi yang mungkin mereka dapat peroleh ${ }^{11}$.

Regulatory capture terjadi pada saat pembentuk peraturan perundang-undangan dalam menyusun peraturan perundangundangan dipengaruhi oleh kelompok kepentingan tertentu, sehingga peraturan perundang-undangan yang seharusnya dibuat untuk kepentingan rakyat justru menjadi alat bagi kelompok kepentingan untuk menjalankan kepentingannya. Dalam pandangan Stigler, fenomena regulatory capture dapat dipahami dengan teori permintaan dan penawaran (supply and demand theory). Disisi permintaan (demand), masyarakat dan dunia usaha menggunakan sumber daya publik dan kekuasaan negara untuk meningkatkan status ekonomi masyarakat dan dunia usaha secara luas. Disisi permintaan (supply), karakteristik proses politik yang ada hanya memungkinkan kelompok kecil kepentingan yang dapat memiliki akses terhadap penyusunan legislasi ${ }^{12}$. Laffont dan Tirole berpendapat bahwa terjadinya regulatory capture disebabkan oleh karena adanya informasi yang tidak berimbang (informational asymmetry) antara industri yang diregulasi dengan pembentuk undangundang ${ }^{13}$.

Berdasarkan pada pandangan tersebut, regulatory capture tidak hanya terjadi akibat bentuk pengaruh yang mengarah pada bentukbentuk perbuatan melawan hukum, melainkan juga bentuk lain seperti keterbatasan akses, informasi, dan pengetahuan yang dimiliki pembentuk undang-undang untuk mengatur sektor tertentu. Disinilah letak perbedaan konsep regulatory capture dengan state capture yang digagas oleh World Bank. State capture fokus pada bentuk pengaruh yang terlarang, tidak sah, dan tertutup (illicit, illegitimate and non-transparent forms of influence) dari kelompok kepentingan kepada pembentuk undang-undang. Tujuannya adalah memasukkan atau mengamankan kepentingan individu, kelompok, atau korporasi dalam perundang-undangan yang sedang disusun melalui pemberian relaksasi, eksklusifitas, atau kemudahan dari pemerintah. Untuk itu, pelaku usaha yang memiliki akses terhadap kekuasaan selalu berupaya mempengaruhi pengambil kebijakan di pemerintahan maupun parlemen agar dapat mendukung kepentingan pelaku usaha dengan pemberian imbalan (illegal fees) kepada pejabat terkait.

World Bank mengidentifikasi bahwa fenomena state capture biasanya terjadi pada negara dengan ekonomi yang sangat terpusat, kontrol sosial yang lemah, dan penyaluran kanal lembaga formal politik dan kepentingan yang tidak terbangun ${ }^{14}$. Fenomena ini mungkin dapat dipahami dengan model Klitgaard. Klitgaard menyatakan bahwa tindak korupsi disebabkan oleh adanya kekuasaan monopolistik ditambah dengan adanya kewenangan diskresi dari penyelenggara negara namun minus

\footnotetext{
M.E. Levine and J.L. Forrence, Op.cit., hlm 167-168

G.J. Stigler, Op.cit., hlm 3.

M.E. Levine and J.L. Forrence, Op.cit., hlm 36.

World Bank, Op.cit., hlm xvi.
} 
akuntabilitas (Corruption (C) equals monopoly power (M) plus discretion by officials (D) minus accountability $(A))^{15}$ atau sering disingkat menjadi $\mathrm{C}=\mathrm{M}+\mathrm{D}-\mathrm{A}$ (Corruption = Monoply + Discretion - Accountability). Jika faktor-faktor yang dinyatakan oleh World Bank diaplikasikan pada model Klitgaard, pemusatan ekonomi merupakan cermin dari kekuasaan monopolistik dan kewenangan diskresi penyelenggara negara, sedangkan kontrol sosial dan suprastruktur politik yang lemah merupakan cermin dari tidak adanya akuntabilitas.

Pergeseran perilaku koruptif dalam pembentukan peraturan perundang-undangan dari eksekutif ke parlemen sebagaimana hasil studi KPK tidak dapat dilepaskan dari kenyataan normatif atas pergeseran kekuasaan membentuk undang-undang dari Presiden ke DPR. Korupsi dan kekuasaan memang ibarat dua sisi dari satu koin mata uang. Korupsi selalu mengiringi perjalanan kekuasaan dan sebaliknya kekuasaan merupakan pintu masuk bagi tindak korupsi ${ }^{16}$.

Undang-Undang Nomor 12 Tahun 2011 menyatakan bahwa pembentukan peraturan perundang-undangan mencakup tahapan perencanaan, penyusunan, pembahasan, pengesahan atau penetapan, dan pengundangan ${ }^{17}$. Sebagai konsekuensi dari pergeseran tersebut, tahap yang kritikal dalam pembentukan peraturan perundang-undangan saat ini ada di parlemen. Paragraf dibawah ini membahas kerentanan pembentukan peraturan perundang-undangan dalam setiap tahapnya.

\section{a. Perencanaan}

Undang-Undang Nomor 10 Tahun 2004 maupun Undang-Undang Nomor 12 Tahun 2011 menggunakan Program Legislasi Nasional (Prolegnas) sebagai instrumen perencanaan pembentukan undang-undang. Tujuannya adalah mewujudkan sistem hukum nasional. Untuk memenuhi tujuan tersebut, Prolegnas memuat skala prioritas program jangka menengah (5 tahun) dan tahunan berdasarkan skala prioritas pembentukan RUU. Penyusunan daftar RUU dalam Prolegnas didasarkan atas perintah konstitusi, perintah MPR, perintah undang-undang lainnya, Sistem Perencanaan Pembangunan Nasional, serta aspirasi dan kebutuhan hukum masyarakat. Penyusunan Prolegnas dilaksanakan oleh DPR dan Pemerintah yang dikoordinasikan oleh DPR melalui badan legislasi. Hasil penyusunan Prolegnas antara DPR dan Pemerintah disepakati menjadi Prolegnas dalam rapat paripurna dan ditetapkan dengan Keputusan DPR.

Prolegnas memiliki peran yang sangat vital dalam pembentukan peraturan perundangundangan. Dalam lingkup mikro, Prolegnas tidak hanya menjadi "tiket masuk" bagi setiap RUU yang hendak dibentuk, melainkan pula menjadi foundation bagi pembentukan RUU itu sendiri. Sedangkan dalam lingkup makro, Prolegnas menjadi suatu alat ukur dari pencapaian tujuan pembangunan hukum nasional yang tujuan akhirnya adalah perwujudan sistem hukum nasional. 
Namun, studi ini menemukan bahwa dari dua periode Prolegnas jangka menengah (2005-2009 dan 2010-2014), penyusunan Prolegnas masih jauh dari harapan. Berdasarkan Keputusan DPR No. 01/DPR RI/III/2004-2005 telah ditetapkan 284 RUU dalam daftar Prolegnas Tahun 20052009. Namun, dari 284 RUU tersebut hanya 130 RUU yang masuk prolegnas tahunan, sedangkan 150 RUU tidak pernah ditetapkan dalam Prolegnas prioritas tahunan. Selain itu, ditemukan pula duplikasi 4 judul RUU dalam daftar tersebut ${ }^{18}$. Sedangkan untuk periode 2010-2014, berdasarkan Keputusan DPR No. 41A/DPR RI/I/2009-2010 ditetapkan sebanyak 247 RUU dimana hanya 116 RUU yang masuk dalam daftar prioritas tahunan, sedangkan sisanya sebanyak 131 RUU tidak pernah ditetapkan dalam prolegnas tahunan.

Studi ini juga menemukan bahwa daftar RUU prioritas tahunan yang ditetapkan tidak selalu berasal dari "long-list" RUU Prolegnas lima tahunan. Selama periode 2005-2009 ada
27 RUU Non-Prolegnas yang masuk dalam daftar RUU prioritas tahunan ${ }^{19}$, sedangkan selama periode 2010-2014 ditemukan 15 RUU Non-Prolegnas yang masuk dalam daftar RUU prioritas tahunan ${ }^{20}$. Masuknya RUU NonProlegnas lima tahunan dalam daftar Prolegnas prioritas tahunan sebagaimana terjadi dalam dua periode Prolegnas tidak terlepas dari pengaturan dalam Undang-Undang Nomor 10 Tahun 2004 dan Undang-Undang Nomor 12 Tahun 2011 yang memberikan kemungkinan untuk mengajukan usul inisiatif RUU di luar Prolegnas dengan kriteria yang sangat terbuka ${ }^{21}$.

Data diatas mengindikasikan adanya permasalahan dalam perencanaan pembentukan peraturan perundang-undangan. Permasalahan yang terjadi tidak hanya menunjukkan kegagalan dalam membuat perencanaan yang achievable dan realistic, namun juga kerentanan dalam proses penyusunan perencanaannya. Penentuan suatu RUU untuk dapat masuk dalam daftar

18 Badan Legislasi DPR RI, Kinerja dan Evaluasi Periode 2004-2009 (Jakarta: Badan Legislasi DPR RI, 2009 ), hlm. 17.

19 Loc.cit.

20 Kelimabelas RUU Non-Prolegnas dan inisiatornya adalah sebagai berikut:(1) Tahun 2011: RUU tentang Pendidikan Tinggi (DPR), RUU tentang Hak Kekayaan Industri (Pemerintah), RUU Pengurusan Piutang Negara dan Daerah (Pemerintah), dan RUU tentang Perubahan atas UU No. 17 Tahun 2008 tentang Pelayaran (Pemerintah); (2) Tahun 2012: RUU tentang Kawasan Pariwisata Khusus (DPR) dan RUU tentang Keinsinyuran (DPR); (3) Tahun 2013: RUU tentang Pengawasan Sediaan Farmasi, Alat Kesehatan, dan Perbekalan Kesehatan Rumah Tangga (DPR), RUU tentang Perubahan atas UU No. 18 Tahun 2003 tentang Advokat (DPR), RUU tentang Pengaturan Minuman Beralkohol (DPR), RUU tentang Panas Bumi (Pemerintah), RUU tentang Perubahan atas UU No. 13 Tahun 2006 tentang Perlindungan Saksi dan Korban (Pemerintah), RUU tentang Perubahan atas Undang-Undang Nomor 23 Tahun 2006 tentang Administrasi Kependudukan (Pemerintah), dan RUU tentang Perubahan atas Harga Rupiah (Pemerintah), dan RUU tentang Perubahan atas UU No. 5 Tahun 1999 tentang Larangan Praktek Monopoli dan Persaingan Usaha Tidak Sehat (DPR); serta (4) Tahun 2014: RUU tentang Radio dan Televisi Republik Indonesia (DPR).

21 Pasal 17 ayat (3) Undang-Undang Nomor 10 Tahun 2004 berbunyi: dalam keadaan tertentu, DPR atau Presiden dapat mengajukan RUU di luar Prolegnas. Pasal 23 ayat (2) Undang-Undang Nomor 12 Tahun 2011 berbunyi: dalam keadaan tertentu, DPR atau Presiden dapat mengajukan RUU di luar Prolegnas mencakup: (1) untuk mengatasi keadaan luar biasa, keadaan konflik, atau bencana alam, dan (2) keadaan tertentu lainnya yang memastikan adanya urgensi nasional atas suatu RUU yang dapat disetujui bersama oleh badan legislasi dan menteri yang menyelenggarakan urusan pemerintahan di bidang hukum. Kriteria "keadaan tertentu" ini yang sering dijadikan pintu masuk bagi RUU Non-Prolegnas dalam daftar Prolegnas prioritas tahunan. 
RUU prioritas tahunan yang hanya ditentukan berdasarkan kesiapan naskah akademik dan draf RUU, menjadi celah bagi kelompok kepentingan untuk memasukkan RUU baru yang telah siap secara administratif untuk masuk sebagai RUU prioritas tahunan meskipun tidak termasuk dalam Prolegnas lima tahunan.

\section{b. Penyusunan}

RUU dapat berasal dari DPR/DPD atau Presiden. RUU dari DPR diajukan oleh anggota DPR, komisi, gabungan komisi, atau badan legislasi, sedangkan RUU yang diajukan oleh Presiden disiapkan oleh menteri/pimpinan lembaga pemerintah non kementerian dengan membentuk panitia antarkementerian. RUU yang telah disusun, selanjutnya dilakukan pengharmonisasian, pembulatan, dan pemantapan konsepsi. Pengharmonisasian, pembulatan, dan pemantapan konsepsi RUU dari DPR dilakukan oleh badan legislasi, sedangkan RUU dari Presiden dilakukan oleh Menteri Hukum dan HAM. Setelah melalui tahap ini, RUU selanjutnya dibahas bersama di panitia kerja pada komisi terkait atau panitia khusus di DPR bersama menteri yang ditunjuk Presiden.

Selain ketentuan diatas, dalam UndangUndang Nomor 12 Tahun 2011 diatur beberapa ketentuan yang harus dipenuhi dalam tahapan penyusunan rancangan peraturan perundangundangan, yaitu:

a. penyusunan rancangan peraturan perundang-undangan (RUU dan Perda) harus disertai dengan naskah akademik (vide Pasal 43);

b. penyusunan rancangan peraturan perundang-undangan dilakukan sesuai dengan teknik penyusunan Peraturan
Perundang-undangan sebagaimana diatur dalam Lampiran II UU (vide Pasal 64);

c. masyarakat berhak memberikan masukan secara lisan dan/atau tertulis (vide Pasal 96); dan

d. penyusunannya mengikutsertakan perancang peraturan perundang-undangan (vide Pasal 98);

Sistem yang dibangun dalam tahapan penyusunan peraturan perundang-undangan seperti diuraikan diatas nampaknya sudah cukup memadai. Namun demikian, penghindaran terhadap celah terjadinya korupsi legislasi sangat tergantung pada kualitas pelaksanaan dari ketentuan-ketentuan tersebut. Oleh karena itu, integritas dan kedisplinan dari setiap pihak yang terlibat dalam penyusunan peraturan perundang-undangan menjadi sesuatu yang tidak dapat dihindari.

\section{c. Pembahasan}

Pembahasan RUU dilakukan oleh DPR bersama Presiden atau menteri yang ditugasi. Pembahasan RUU dilakukan melalui 2 (dua) tingkat pembicaraan, yaitu pembicaraan tingkat I dalam rapat komisi, rapat gabungan komisi, rapat badan legislasi, rapat badan anggaran, atau rapat panitia khusus, dan pembicaraan tingkat II dalam rapat paripurna. Dalam pembicaraan tingkat I, pemrakarsa RUU, DPR atau Presiden atau menteri yang mewakili, menyampaikan penjelasan atas pengajuan RUU sedangkan pihak lainnya kemudian menyampaikan pandangan mengenai setuju atau tidaknya RUU yang diajukan untuk dilanjutkan pembahasan bersama. Apabila disetujui, maka pembahasan dilanjutkan dengan pembahasan daftar inventarisasi masalah. Pembahasan tingkat I ditutup dengan penyampaian pendapat mini 
setiap fraksi di DPR dan Presiden atas RUU yang telah dibahas. Pembicaraan tingkat II merupakan pengambilan keputusan dalam rapat paripurna yang didahului dengan penyampaian laporan dan hasil pembicaraan tingkat I, pernyataan persetujuan atau penolakan dari tiap fraksi DPR, dan penyampaian pendapat akhir Presiden.

Titik penting dari interaksi antara DPR dan Pemerintah dalam pembahasan RUU adalah kertas kerja yang berupa Daftar Inventarisasi Masalah (DIM). DIM disusun oleh Pemerintah untuk RUU inisiatif DPR dan oleh DPR untuk RUU inisiatif Presiden. DIM merupakan kertas kerja yang memuat usul dan penjelasan perubahan dan rumusan perubahan atas RUU. Karakteristik usulan dalam DIM meliputi: "tetap" apabila materi dan rumusan suatu ayat, pasal, judul paragraf, judul bagian, atau judul bab disetujui, "perubahan redaksional" bila materi suatu ayat, pasal, judul paragraf, judul bagian, atau judul bab disetujui namun diusulkan perubahan rumusan, dan "perubahan substansi" apabila materi dan rumusan suatu ayat, pasal, judul paragraf, judul bagian, atau judul bab tidak disetujui. DIM DPR disusun oleh masing-masing fraksi yang mewakili kekuatan politik di DPR dan dikompilasi dalam satu kertas kerja untuk dibahas bersama wakil Pemerintah, sedangkan DIM Pemerintah hanya terdiri atas satu pandangan/sikap untuk setiap substansi dan rumusan suatu ayat, pasal, judul paragraf, judul bagian, atau judul bab dalam RUU yang penyusunannya dilakukan oleh menteri-menteri yang ditugasi oleh Presiden untuk mewakili dalam pembahasan bersama DPR.

Di tahapan pembahasan RUU, studi ini mencatat celah yang cukup lebar yang menimbulkan kerentanan pada bentuk korupsi legislasi. Salah satu penyebabnya adalah karena tidak adanya pengintegrasian pembahasan hasil-hasil yang dimuat dalam naskah akademik dalam proses pengambilan keputusan. DIM hanya berkutat pada materi dan rumusan suatu ayat, pasal, judul paragraf, judul bagian, atau judul bab, sehingga asumsi-asumsi yang dibangun dan hasil-hasil penalaahan masalah yang dimuat dalam naskah akademik tidak pernah teruji. Pembahasan RUU yang parsial semacam ini tentu sangat rentan terhadap masuknya kepentingan yang dapat memberikan eksternalitas negatif bagi publik. Kelompok kepentingan ekonomi yang memiliki akses terhadap kekuasaan dapat dengan mudah menyisipkan klausul tertentu yang dapat menopang kepentingannya atau merubah rumusan yang mengarah pada bentuk relaksasi atau eksklusifitas.

\section{d. Pengesahan/Penetapan}

RUU yang telah disetujui bersama oleh DPR dan Presiden disampaikan oleh Pimpinan DPR kepada Presiden dalam jangka waktu paling lama 7 (tujuh) hari terhitung sejak tanggal persetujuan bersama untuk disahkan menjadi Undang-Undang. RUU disahkan oleh Presiden dengan membubuhkan tanda tangan dalam jangka waktu paling lama 30 (tiga puluh) hari terhitung sejak RUU tersebut disetujui bersama oleh DPR dan Presiden. Dalam hal RUU tidak ditandatangani oleh Presiden dalam tersebut, RUU tersebut sah menjadi Undang-Undang dan wajib diundangkan.

Dalam nalar umum, pada tahap ini nampak tidak ada tempat bagi korupsi legislasi. Namun, kasus penghilangan "ayat tembakau" di Undang-Undang Kesehatan dapat menjadi referensi bahwa korupsi legislasi 
juga memungkinkan terjadi setelah selesainya pembahasan suatu RUU ${ }^{21}$. Untuk itu, perlu dibuat semacam checking system rules untuk menghindari terjadinya kesalahan baik karena kelalaian maupun kesengajaan pada tahap akhir pembentukan peraturan perundang-undangan.

\section{e. Pengundangan}

Pengundangan peraturan perundangundangan dalam Lembaran Negara (state gazette) dilaksanakan oleh menteri yang menyelenggarakan urusan pemerintahan di bidang hukum. Dalam tahap ini, kecil kemungkinan terjadi korupsi legislasi karena dalam pengundangan, menteri hanya membubuhkan tanda tangan pada naskah undang-undang yang ditetapkan/disahkan Presiden. Naskah undang-undang yang telah ditandatangani disampaikan oleh Menteri kepada Menteri Sekretaris Negara untuk disimpan.

\section{Antisipasi Peluang Korupsi dalam} Pembentukan Peraturan Perundangundangan

Secara keseluruhan, pertanyaan kunci dari studi ini adalah bagaimana setiap tahapan dari pembentukan peraturan perundang-undangan didesain agar dapat meminimalisasi secara langsung atau tidak langsung peluang terjadinya korupsi legislasi. Dengan mendasarkan pada model Klitgaard, studi ini mengusulkan 4 (empat) prinsip yang dapat diterapkan untuk mencegah terjadinya korupsi legislasi. Keempat prinsip tersebut meliputi: ketatalaksanaan, profesionalitas, justifikasi, dan partisipasi publik.

\section{a. Ketatalaksanaan}

Salah satu aspek penting dalam pembentukan peraturan perundang-undangan yang baik adalah ketatalaksanaan yang mencakup metode dan tata kerja dari lembaga-lembaga yang terlibat dalam pembentukan peraturan perundang-undangan. Sebagaimana diketahui, selain kementerian hukum yang berdasarkan Undang-Undang Nomor 12 Tahun 2011 diberikan tanggungjawab dalam pengelolaan peraturan perundang-undangan, terdapat beberapa lembaga pemerintah lainnya yang juga memiliki peran yang tidak dapat diabaikan, seperti Kementerian Sekretariat Negara dan Sekretariat Kabinet yang memberikan pendapat akhir sebelum suatu rancangan ditetapkan oleh Presiden ${ }^{22}$. Untuk itu, diperlukan kerjasama yang baik diantara lembaga-lembaga tersebut.

Dalam konteks ini, ketatalaksanaan merupakan prinsip yang harus ada untuk menjamin konsistensi dan dapat diprediksinya arah dan proses pembentukan peraturan 
perundang-undangan. Ketatalaksanaan dapat berupa aturan mengenai:

a. metodedan mekanisme pengharmonisasian, pembulatan, dan pemantapan konsepsi rancangan peraturan perundang-undangan;

b. metode asesmen rancangan peraturan perundang-undangan yang akan ditetapkan/ disetujui Presiden (ex-ante evaluation);

c. metode evaluasi peraturan perundangundangan (ex-post evaluation).

Dengan terbangunnya ketatalaksanaan pembentukan peraturan perundang-undangan, diharapkan badan-badan pemerintah yang terkait dengan pengelolaan peraturan perundang-undangan dapat memiliki kesamaan sikap/pandangan atas kualitas peraturan perundang-undangan yang hendak diwujudkan.

\section{b. Profesionalitas}

Salah satu perubahan mendasar dari UUD 1945 adalah pergeseran kekuasaan membentuk Undang-Undang dari Presiden ke DPR. Melalui ketentuan Pasal 20 ayat (1) UUD 1945 tugas berat pembentukan hukum yang kekuatannya hanya satu tingkat dibawah konstitusi telah beralih dari lembaga pemerintah ke lembaga parlemen. Pergeseran ini tentu menimbulkan dampak yang serius terhadap aspek formal dan material dari hukum yang ditetapkan karena DPR merupakan lembaga politik yang anggotanya memiliki kualifikasi dan kompetensi yang beragam yang masa baktinya dibatasi oleh waktu tertentu. Untuk itu, agar tidak terjadi informational asymmetry yang mengarah ke bentuk-bentuk state capture, diperlukan dukungan yang memadai dalam pelaksanaan tugas DPR sebagai pembentuk Undang-Undang.

Undang-Undang Nomor No. 12 Tahun 2011 menyatakan bahwa setiap tahapan pembentukan peraturan perundang-undangan mengikutsertakan perancang peraturan perundang-undangan serta peneliti dan tenaga ahli. Meskipun belum secara detail diatur makna "ikut serta" dalam Undang-Undang, namun semangat pelibatanstaf yang memiliki kualifikasi tertentu dan kecakapan teknis di bidang peraturan perundang-undangan dan kalangan profesional dalam pembentukan peraturan perundang-undangan perlu dioptimalkan.

Dalam penjelasan umum Undang-Undang Nomor No. 10 Tahun 2004 dinyatakan bahwa peran tenaga perancang peraturan perundangundangan adalah menyiapkan, mengolah, dan merumuskan rancangan peraturan perundang-undangan. Dengan kata lain, tugas dan fungsi perancang adalah menjabarkan serta menuangkan kehendak pembentuk undang-undang ke dalam bentuk norma-norma atau pasal-pasal. Dengan demikian seorang perancang semestinya tidak hanya menguasai teknik merancang suatu rancangan peraturan perundang-undangan tetapi juga mampu memahami rancangan peraturan perundangundangan dengan seutuhnya, meliputi aspek filosofis, yuridis maupun sosiologis sehingga undang-undang yang dihasilkan memenuhi asas-asas pembentukan peraturan perundangundangan yang baik.

Dalam kajian hukum, banyak kalangan yang seringkali melupakan peran penting dari

23 A. Seidman and R.B. Seidman, "ILTAM: Drafting Evidence-Based Legislation for Democratic Social Change", Boston University Law Review Vol. 89: 435-484. 
perancang. Padahal dalam praktik, kegiatan penyusunan peraturan perundang-undangan oleh perancang akan sangat berdampak pada substansi hukum dan penjabarannya dalam peraturan perundang-undangan yang dibentuk $^{23}$. Karena 'the devil is on the detail' dimana perancang berperan penting dalam detailing prosesnya, maka menjadi hal yang sangat penting dalam konteks pembentukan peraturan perundang-undangan yang bebas korupsi untuk memiliki perancang yang berintegritas dan profesional. Hanya perancang yang memiliki kualifikasi semacam itu yang dapat memberikan umpan balik yang objektif (objective feedback) kepada pembuat kebijakan sehingga dapat mencegah peluang terjadinya korupsi legislasi.

\section{c. Justifikasi}

Penyusupan kepentingan dalam pembentukan peraturan perundang-undangan dapat diminimalisasi apabila DPR dan Pemerintah memiliki kesamaan pandangan atas RUU yang hendak diwujudkan. Naskah akademik dapat menjadi katalisator bagi tercapainya kesamaan pandangan tersebut karena sebagai sebuah policy paper naskah akademik memuat justifikasi dari dibentuknya suatu undangundang. Oleh sebab itu, studi ini menyarankan agar pembahasan RUU di DPR tidak hanya membahas DIM pasal per pasal, namun meliputi pula pembahasan naskah akademik RUU tersebut. Dengan membahas pula naskah akademik RUU, DPR dan Pemerintah sejak dini telah dapat menangkap esensi dan tujuan pengaturan sehingga dapat mengurangi distorsi yang berakibat pada ambiguitas RUU yang dibuat, sekaligus mempercepat penyelesaian pembahasan RUU.

Selain itu, naskah akademik yang telah dibahas juga dapat digunakan sebagai semacam memorie van toelichting ${ }^{24}$ yang dapat dibaca oleh semua orang sehingga, misalnya, dapat dimengerti mengapa pembentuk Undang-Undang mengambil kebijakan tersebut. Kebijakan yang diputuskan dengan pertimbangan yang rasional dan dapat dipertanggungjawabkan tentu dapat mengurangi gesekan dengan pemangku kepentingan lainnya yang menganggap hak konstitusionalnya "terganggu" atas ditetapkannya suatu Undang-Undang. Andaipun hal tersebut harus terjadi, dengan tanpa menghilangkan unsur kemandirian hakim dalam memutus, hakim-hakim konstitusi yang diberi kewenangan oleh UUD untuk menguji UndangUndang dapat menggunakan naskah akademik atas RUU yang diuji sebagai pertimbangan dalam membuat putusan.

\section{d. Partisipasi Publik}

Salah satu hal yang penting dalam pembentukan peraturan perundang-undangan 
adalah adanya partisipasi publik. UndangUndang Nomor 12 Tahun 2011 menyatakan transparansi sebagai salah satu asas yang wajib diikuti oleh setiap pembentuk peraturan perundang-undangan. Dalam Undang-Undang diatur bahwa orang perseorangan atau kelompok orang yang mempunyai kepentingan atas substansi rancangan berhak memberikan masukan secara lisan atau tertulis melalui rapat dengar pendapat umum, kunjungan kerja, sosialisasi, seminar/lokakarya/diskusii ${ }^{25}$, namun dalam tahap apa dan bagaimana mekanismenya belum diatur dalam Undang-Undang.

Partisipasi masyarakat semestinya dinyatakan dalam Undang-Undang sebagai bagian dari tahap yang dilalui dalam pembentukan peraturan perundang-undangan. Dalam ketentuan Undang-Undang, partisipasi masyarakat merupakan "hak", sehingga tentu hak masyarakat tersebut hanya dapat dijalankan apabila ada kehendak dari penyusun rancangan peraturan perundang-undangan untuk menyelenggarakan kegiatan-kegiatan tersebut. Di negara lain, sebagai contoh di Belanda, sejak 2009 telah dilaksanakan internet-based consultation atau konsultasi publik melalui internet dimana Ministry of Justice akan mempublikasikan rancangan act of parliament yang sedang disusun (beserta informasi mengenai implikasi dari pengaturannya) di webpage selama 12 minggu dan setiap orang dapat memberikan masukan atas publikasi dimaksud ${ }^{26}$. Hal serupa juga dijumpai di Australia, Kanada, Denmark, dan
Inggris ${ }^{27}$. Meskipun di Indonesia tidak perlu meniru persis seperti yang dilakukan di Belanda dan negara-negara tersebut, pada intinya perlu dipertimbangkan adanya tahapan konsultasi/ uji publik atas rancangan peraturan perundangundangan yang akan ditetapkan.

\section{Penutup}

Berdasarkan uraian diatas, dapat ditarik kesimpulan bahwa secara normatif UndangUndang No. 10 Tahun 2004 yang telah disempurnakan dengan Undang-Undang Nomor 12 Tahun 2011, sudah cukup antisipatif dalam menciptakan mekanisme pembentukan peraturan perundang-undangan yang mengarah pada bentuk pencegahan terhadap praktik korupsi legislasi. Pembentukan peraturan perundang-undangan yang meliputi tahapan perencanaan, penyusunan, pembahasan, pengesahan atau penetapan, dan pengundangan telah mendekati proses pembentukan peraturan perundang-undangan seperti yang digambarkan dalam synoptic policyphases theory. Namun demikian, perwujudan pembentukan peraturan perundang-undangan yang baik dan bersih sangat tergantung pada kualitas pelaksanaannya. Dari lima tahapan pembentukan peraturan perundangundangan tersebut, studi ini menemukan tahap perencanaan dan pembahasan mengandung kerawanan yang cukup tinggi, sedangkan pada tahap penyusunan, penetapan/pengesahan, dan pengundangan kecil kemungkinan terjadi.

Pasal 96 Undang-Undang Nomor 12 Tahun 2011 tentang Pembentukan Peraturan Perundang-undangan.

26 OECD, OECD Reviews of Better Regulation in the Netherlands (Paris: OECD, 2009), hlm 64.

27 Jan A.B. Janus, 2013, A Compilation of Introductions on Legislation in the Netherlands (The Hague: ROM B.V., 2013), hlm 112. 
Untuk meminimalisasi peluang terjadinya korupsi legislasi dalam pembentukan peraturan perundang-undangan, studi ini mengusulkan empat hal yang dapat diterapkan dalam rangka melengkapi penyempurnaan proses pembentukan peraturan perundangundangan yang diatur dalam Undang-Undang Nomor 12 Tahun 2011 tentang Pembentukan Peraturan Perundang-undangan, meliputi ketatalaksanaan, profesionalitas, justifikasi, dan partisipasi publik. Dengan terwujudnya pembentukan peraturan perundangan yang baik, prinsip negara hukum yang dicitakan oleh setiap elemen bangsa diharapkan betul-betul dapat terwujud.

\section{DAFTAR PUSTAKA}

\section{Buku}

Bahar, Saafroedin, et al., Risalah Sidang Badan Penyelidik Usaha-Usaha Persiapan Kemerdekaan Indonesia (BPUPKI)-Pantia Persiapan Kemerdekaan Indonesia (PPKI) 28 Mei 1945 22 Agustus 1945 (Jakarta: Sekretariat Negara RI, 1995)

Janus, J.A.B, A Compilation of Introductions on Legislation in the Netherlands (The Hague: ROM B.V., 2013)

Klitgaard, R., et al., Corruption Cities: A Practical Guide To Cure and Prevention (Washington D.C.: Word Bank Publication, 2000)

Majelis Permusyawaratan Rakyat Republik Indonesia, "Hasil Perubahan dan Naskah Asli UUD 1945", dalam Panduan Pemasyarakatan UndangUndang Dasar Negara Republik Indonesia Tahun 1945 (Jakarta: Sekretariat Jenderal MPR RI, tahun 2005)

Tim Penyusun Revisi Naskah Komprehensif Perubahan Undang-Undang Dasar Negara Republik Indonesia Tahun 1945, Latar Belakang, Proses, dan Hasil Pembahasan 1999-2002, Buku II Sendi-Sendi/Fundamental Negara (Jakarta: Sekretariat Jenderal dan Kepaniteraan Mahkamah Konstitusi, 2010)

\section{Makalah / Artikel / Prosiding / Hasil Penelitian}

Badan Legislasi DPR RI, Kinerja dan Evaluasi Periode 2004-2009 (Jakarta: Badan Legislasi DPR RI, 2009)

Laffont, J. J., and Tirole, J., "The Politics of Government Decision Making. A Theory of Regulatory Capture", Quarterly Journal of Economics 106(4) (1991)

Levine, M. E., and Forrence, J. L. (1990). "Regulatory capture, public interest, and the public agenda. Toward a synthesis", Journal of Law Economics \& Organization 6 (1990)

Mahendra, Yusril Ihza, "Bahan Penjelasan Mensesneg pada Rapat Kerja dengan Komisi II DPR RI tanggal 25 Januari 2006" (Disampaikan pada Rapat Kerja Menteri Sekretaris Negara Komisi II DPR RI, Jakarta, 25 Januari 2006)

OECD, OECD Reviews of Better Regulation in the Netherlands (Paris: OECD, 2009)

OECD, OECD Reviews of Regulatory Reform: Indonesia, Government Capacity to Assure High Quality Regulation (Paris: OECD, 2012)

Otto, J.M., Stoter, W.S.R., and Arnscheidt, J., Using legislative Theory to Improve Law and Development Projects", RegelMaat afl. 2004/4

Sanusi, Arsyad, "Relasi antara Korupsi dan Kekuasaan", Jurnal Mahkamah Konstitusi Vol. 6 No. 2 (2009)

Seidman, A. and Seidman, R.B., "ILTAM: Drafting Evidence-Based Legislation for Democratic Social Change", Boston University Law Review Vol. 89: 435-484

Stigler, G.J., "The Theory of Economic Regulation", The Bell Journal of Economics and Management Science Vol. 2, No. 1 (Spring, 1971)

World Bank, Anticorruption in Transition: A Contribution to the Policy Debate, (Washington D.C.: World Bank, 2000)

\section{Internet}

Komisi Pemberantasan Korupsi, “DPR Masih Rawan Korupsi", Komisi Pemberantasan Korupsi, http:// kpk.go.id/id/berita/berita-sub/1358-dpr-masihrawan-korupsi (Diakses 1 Oktober 2014)

Tempo, "Ayat Tembakau Hilang dari UndangUndang Kesehatan", Tempo, http://www. tempo.co/read/news/2009/10/07/063201344/ Ayat-Tembakau-Hilang-dari-Undang-undangKesehatan (diakses tanggal 1 Oktober 2014) 
Tilburg University, "Parliamentary Documents University Library for Visitors", Tillburg University, https://www.tilburguniversity.edu/ about/university-library/searching-information/ parliamentary-documents/ (diakses 1 Oktober 2014)

\section{Peraturan}

Undang-Undang Dasar Negara Republik Indonesia Tahun 1945
Undang-Undang Nomor 10 Tahun 2004 tentang Pembentukan Peraturan Perundang-undangan (Lembaran Negara Republik Indonesia Tahun 2004 Nomor 53, Tambahan Lembaran Negara Republik Indonesia Nomor 4389)

Undang-Undang Nomor 12 Tahun 2011 tentang Pembentukan Peraturan Perundang-undangan (Lembaran Negara Republik Indonesia Tahun 2011 Nomor 82, Tambahan Lembaran Negara Republik Indonesia Nomor 5234) 